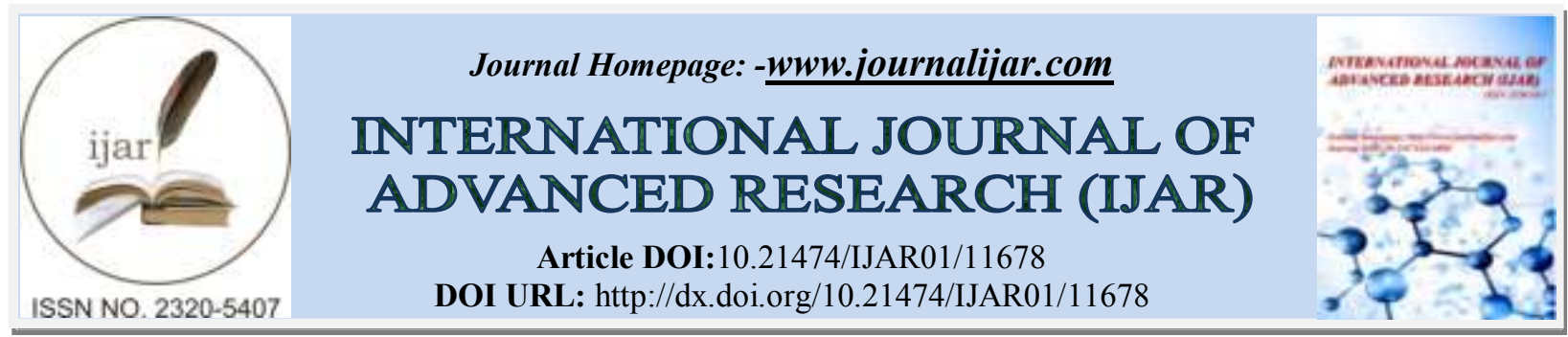

RESEARCH ARTICLE

\title{
THE MEDIATING EFFECT OF STUDENTS' PERCEPTION TOWARDS SOCIAL MEDIA ON THE RELATIONSHIP BETWEEN VOCABULARY LEARNING ATTITUDE AND LANGUAGE SKILLS DEVELOPMENT
}

Ed B. Bautista

College of Teacher Education, University of Mindanao, Matina Campus, Davao City Philippines.

\section{Manuscript Info}

.1.......................

Manuscript History

Received: 10 July 2020

Final Accepted: 14 August 2020

Published: September 2020

Key words:-

Education, Social Media, Vocabulary Learning Attitude, Language Skillsdevelopment, Philippines

\section{Abstract}

This study determined the mediating effect of students' perception towards social media on the relationship between vocabulary learning attitude and language skills development. The quantitative approach using the correlational technique and mediation analysis were utilized in this study with a sample of 350 students coming from the senior high school department of the University of Mindanao main campus. Sets of adapted survey questionnaires were used in obtaining data from the respondents which were subjected for content validity and reliability analysis. The data were analysed using the Mean, Pearson-r, Multiple Regression Analysis, and Medgraph using Sobel z-test. The results reveal that the levels of students' perception towards social media, vocabulary learning attitude, and language skills development are high or oftentimes evident. Moreover, a significant partial mediation existed between these variables. A significant partial mediation of the students' perception towards social media on the relationship between vocabulary learning attitude and language skills development was proven in the study.

Copy Right, IJAR, 2020,. All rights reserved.

\section{Introduction:-}

Language skills development play a vital role in developing the students' academic capabilities and if not dealt seriously it can hamper students' communication development. In line with this, the students who were identified with poor listening and speaking skills might encounter problems in developing their language skills (Tomblin, Zhang, Buckwalter, \& Catts, 2009). In the recent language proficiency test survey done by the Hopkins International Partners, students from the Philippines got a lower average in English proficiency compared to Thailand. This simply implies that the Philippines is experiencing a sudden decline in the rank of English proficient Asian countries (GMA News Online, 2018).

With the problem stated above, many scholars suggested the importance of utilizing vocabulary learning to aide language development, since vocabulary learning is an important piece of developing students' language skills (Zimmerman, 2009). This is supported by Gifford (2013) when he mentioned that language cannot exist without vocabulary hence vocabulary must be diligently taught to the students to solidify their language skills. He further added that a person who has a wider set of vocabulary knowledge has a better ability to communicate and understand. Another way of developing students' language skills is through the use of technological tools such as the social media. Educators may opt to use social media since it captures interest for learners and promotes 
collaborative learning (Lau, 2012). However, teachers should guide the students in utilizing social media as a learning tool. Likewise, Junco, Heiberger, and Loken (2011) conducted an experiment to determine if twitter can be a good avenue for numerous forms of academic and co-curricular activities, and they found out that it can be used for educational purposes to lure students' interests.

Henceforth, the facts stated above are the reasons why the researcher is interested to determine the mediating effect of students' perception towards social media on the relationship between vocabulary learning attitude and language skills development of students using the indicators explored since no study has been conducted yet. Through further exploration, it may provide some insights on how students' perception towards social media can help the academic community. Likewise, academic institutions will have an idea why these phenomena are happening and how students' perception towards social media can affect the relationship between vocabulary learning attitude and language skills development of students.

\section{Method:-}

This research utilized the descriptive-correlation deign. Descriptive study describes the attitudes and behaviours during the investigation, while correlational research covers ascertaining statistical associations between two variables (Vanderstoep\& Johnston, 2009). Additionally, the purpose of correlation design is to find out the strength of relationship between the variables being studied (Creswell, 2013). Moreover, this investigation operated mediation analysis developed by Baron and Kenny (1986) which primarily focused to distinguish and explain the component of procedure that bring about the strength of association between vocabulary learning attitude and language skills through the incorporation of a third variable which is the students' perception towards social media acting as the potential mediating variable.

There were 350 senior high school students who participated in the conduct of this study from the University of Mindanao main campus. Slovin's Equation was used in determining the random of population and selection of the respondents via simple random sampling. Simple random sampling is described by Sevil and Yildiz (2017) as a situation when a researcher chooses a set of samples from a large population. Specifically grade 12 students were the chosen study participants coming from different academic strands namely; ABM (Accountancy Business and Management), HUMSS (Humanities and Social Sciences), IA (Industrial Arts), STEM (Science and Technology, Engineering and Mathematics) and HE (Home Economics).

This study employed a survey questionnaire that has three parts, one part for every variable. It was validated and revised based on the recommendations of the experts. Prior to the conduct of actual survey, the researcher conducted a preliminary survey with a total of 30 respondents for reliability testing. The preliminary data gathered were subjected to internal consistency type of validity test using the Cronbach's alpha. With a reliability test of 73 items the overall summary result has a value of Cronbach alpha at .873 which indicates that the data used in the study is valid and the instrument has a very high reliability.

The first part questionnaire on the level of students' perception on social media is composed of twenty items. It is adapted from the study of Anankulladetch, (2017), the researcher modified the instrument to make it fit to the context of the study. The second questionnaire utilized is the vocabulary learning attitude from the study of Vasu and Senkamalam (2015). Similarly, the items are revised based on the context of this study. Vocabulary learning attitude questionnaire has two indicators: importance of vocabulary and sources of new words; every indicator contains five questions.

The last part of the questionnaire employed in this study is the language skills development constructed by Griffiths (2004). It is composed of four indicators: speaking skill, listening skill, reading skill, and writing skill, having five questions each. The scale of means was used to interpret the level of students' perception towards social media as shown below.

With the data gathered in this study, the subsequent statistical tools were employed.

Mean was used to quantity the level of students' perception towards social media, vocabulary learning attitude as well as the language skills development to answer objective from one to three. 
Pearson Product Moment Correlational was utilized to ascertain the relationship of students' perception towards social media, vocabulary learning attitude as well as the language skills development.

Medgraph using Sobel z-test was employed to measure if students' perception towards social media mediates on the relationship between vocabulary learning attitude and language skills development. To test the significance of mediation Sobel z-test was employed.

Mediation Test method is established by Baron and Kenny (1986); it is applied universally and is the most recognized technique as an essential tool to calculate the mediation effects of variables. The process was used to examine the mediating effect of student's perception towards social media on the relationship between vocabulary learning attitude and language skills development. This involves the regression of the mediator students' perception towards social media on the independent variable (vocabulary learning attitude); second the regression of the dependent variable (language skills development); and third the regression of the dependent variable (language skills development) on both the independent and on the mediator (students' perception towards social media). For the mediation to hold in the first regression equation, the independent variable must affect the dependent variable. In the final regression, the mediator must affect the dependent variable even to the exclusion of the independent variable.

Additionally, Baron and Kenny (1986) stated that a subsequent regression analysis must be done to identify the mediating role of a variable. Thus, in the current study, language skills development was regressed on both students' perception towards social media and vocabulary learning attitude.

\section{Results:-}

Presented in Table 1 are the data on the level of vocabulary learning attitude. The level of vocabulary leaning attitude were measured in terms of sources of new words and importance of vocabulary. The weighed means of each criterion was computed, in which the level of vocabulary learning attitude has a weighed mean of 3.60 with a standard deviation of 0.29 and descriptive interpretation of high. This means that vocabulary learning attitude is oftentimes manifested by the respondents. The results revealed that sources of new words have the higher mean score with the value of 4.08 which is described as high. The second indicator which is the importance of vocabulary has obtained a lower mean score of 3.11 which is also described also as high.

Table 1:-Level of Vocabulary Learning Attitude.

\begin{tabular}{|l|l|l|l|}
\hline Indicator & SD & Mean & Descriptive Level \\
\hline Sources of New Words & 0.46 & 4.08 & High \\
\hline Importance of Vocabulary & 0.87 & 3.11 & High \\
\hline Overall & $\mathbf{0 . 2 9}$ & $\mathbf{3 . 6 0}$ & High \\
\hline
\end{tabular}

As revealed in Table 2, the level of language skills development was measured based on the following indicators: speaking skill, writing skill, listening skill and reading skill. Language skills development has an overall weighted mean score of 4.07 and a standard deviation of 0.03 with a verbal interpretation of high. This means that language skills development is oftentimes manifested by the respondents. For specific indicators' results, the highest means are the speaking skill with a mean value of 4.25 and a descriptive level of very high. This means that among the language skills development speaking skill is always practiced by the respondents. On the other hand, the other indicators' results revealed as high for writing skill with a mean value of 4.18 , listening skill with a mean value of 3.93, and reading skill with a mean value of 3.93. All of the aforementioned indicators got a descriptive level of high.

Table 2:-Level of Language Skills Development.

\begin{tabular}{|l|l|l|l|l|}
\hline Indicator & SD & & Mean & Descriptive level \\
\hline Speaking Skill & 0.47 & & 4.25 & Very High \\
\hline Writing Skill & 0.42 & & 4.18 & High \\
\hline Reading Skill & 0.44 & 3.93 & High \\
\hline Listening Skill & 0.51 & & 3.93 & High \\
\hline Overall & $\mathbf{0 . 0 3}$ & & $\mathbf{4 . 0 7}$ & High \\
\hline
\end{tabular}


In Table 3, students' perception towards social media has a weighted mean of 3.76 with the standard deviation of 0.08 and a verbal interpretation of high. The result shows that perceived usefulness has the highest mean value of 3.93 which is described as high. The second highest indicator of students' perception towards social media is the students' academic performance which is described as high with a mean score of 3.83. The third highest indicator of students' perception towards social media is the interactivity with peers which has a mean score of 3.76 which also has a descriptive level of high. Another indicator of students' perception towards social media is the engagement which has a weighted mean of 3.68 and a descriptive level of high. The lowest mean in the students' perception towards social media is the interactivity with teachers with the mean value of 3.58 with a high descriptive equivalent.

Table 3:-Level of Students' Perception towards Social Media.

\begin{tabular}{|l|l|l|l|}
\hline Indicator & SD & Mean & Descriptive level \\
\hline Perceived Usefulness & 0.72 & 3.93 & High \\
\hline Students' Academic performance & 0.79 & 3.83 & High \\
\hline Interactivity with Peers & 0.93 & 3.76 & High \\
Engagement & 0.90 & 3.68 & High \\
Interactivity with Teachers & 0.85 & 3.58 & High \\
\hline Overall & $\mathbf{0 . 0 8}$ & $\mathbf{3 . 7 6}$ & High \\
\hline
\end{tabular}

Depicted in Table 4 is the result of the test of relationship between vocabulary learning attitude and language skills development. This relationship was tested at 0.05 level of significance. In particular, it revealed a positive and significant relationship between all indicators of vocabulary learning attitude and language skills development, as revealed in the P-value of less than 0.05 , and with an $r$ value of .219 on reading skill, .179 on writing skill, .338 on listening skill and .214 on speaking skill, with an overall value of 309 .

Table 4:-Correlation between Vocabulary Learning Attitude and Language Skills Development.

\begin{tabular}{|l|l|l|l|l|l|}
\hline \multicolumn{7}{|l|}{ language skills development } \\
\hline Vocabulary Learning Attitude & Reading & Writing & Listening & Speaking & Overall \\
\hline Importance of Vocabulary & $.219^{*}$ & $.179^{*}$ & $.338^{*}$ & $.241^{*}$ & $.309^{*}$ \\
& $(.000)$ & $(.000)$ & $(.000)$ & $(.000)$ & $(.000)$ \\
\hline Sources of New Words & $.506^{*}$ & $.354^{*}$ & $.586^{*}$ & $.556^{*}$ & $670^{*}$ \\
& $(.000)$ & $(.000)$ & $(.000)$ & $(.000)$ & $(.000)$ \\
\hline Overall & $.754^{*}$ & $.724^{*}$ & $.826^{*}$ & $.904^{*}$ & $.628^{*}$ \\
& $(.000)$ & $(.000)$ & $(.000)$ & $(.000)$ & $(.000)$ \\
\hline
\end{tabular}

The overall result reflects that vocabulary learning attitude is positively correlated with language skills development since the overall $\mathrm{r}$-value is .628 with a $\mathrm{p}$ value $<.05$, hence rejecting the null hypothesis. This shows that the increase in vocabulary learning attitude would also likely increase language skills development of the students.

Illustrated in Table 5 is the result of the test of relationship between language skills development and students' perception towards social media. The result shows that the overall values reveal a positive and significant relationship between language skills development and students' perception towards social Media.

Table 5:-Correlation between Students' Perception towards Social Media and Language Skills Development.

\begin{tabular}{|l|l|l|l|l|l|}
\hline Language Skills Development & Reading & Writing & Listening & Speaking & Overall \\
\hline Students'.Perception towards Social Media & $.381^{*}$ & $.254^{*}$ & $.535^{*}$ & $.334^{*}$ & $.465^{*}$ \\
\hline & $(.000)$ & $(.000)$ & $(.000)$ & $(.000)$ & $(.000)$ \\
\hline
\end{tabular}

The overall result reflects that language skills development is positively correlated with students' perception towards social media since the overall $\mathrm{r}$-value is .465 with a $\mathrm{p}$-value $<.05$, hence rejecting the null hypothesis. Hence, there is a positive association of the two variables.

Displayed in Table 6 is the result of the test of relationship between vocabulary learning attitude and students' perception towards social media. The result shows that the overall values reveal a positive and significant 
relationship between vocabulary learning attitude and students' perception towards social media $(\mathrm{r}=.458, \mathrm{p}<.05)$. More specifically, all of the indicators of vocabulary learning attitude correlate positively with students' perception towards social media, namely importance of vocabulary $(\mathrm{r}=.420, \mathrm{p}<.05)$, and sources of new words, hence the rejection of the null hypothesis at .05 level of significance.

Table 6:-Correlation between Vocabulary Learning Attitude and Students' Perception towards Social Media.

\begin{tabular}{|l|l|}
\hline Vocabulary Learning Attitude & Students Perception towards Social Media \\
\hline Importance of Vocabulary & $.420^{*}$ \\
\hline Sources of New Words & $(.000)$ \\
\hline & $.308^{*}$ \\
\hline Overall & $(.000)$ \\
\hline & $.458^{*}$ \\
\hline
\end{tabular}

Shown in Table 7 is the regression analysis on the mediating effect of students' perception towards social media on the relationship between vocabulary learning attitude and language skills development. The data in this table were used as input to the medgraph in Figure 1.

As evident in the study of Baron and Kenny (1986), there are three steps to be met for a third variable to be acting as mediator, in Table 7 these are categorized as steps 1 to 3, step 4 is the final step. In Step 1 (Path C) vocabulary learning attitude as independent variable (IV) significantly predicts language skills development, the dependent variable (DV). In Step 2 (Path A) vocabulary learning attitude (IV) significantly predicts students' perception towards social media, the mediator (MV). In Step 3, students' perception towards social media, the mediator (MV) significantly predicts language skills development. In Step 4 the combined effect of vocabulary learning attitude and students' perception towards social media on language skills development is significant.

\section{Data entry for the different paths}

As a matter of triangulation, further mediation analysis through medgraph is warranted, involving the Sobel Test to assess the significance of mediation effect. In line with the study of Baron and Kenny (1986), if the effect of the IV on the DV becomes non-significant at the final step in the analysis, full mediation will be achieved.

It means all of the effects are mediated by the mediating variable. If the regression coefficient is substantially reduced at the final step but remains significant, only partial mediation is obtained. It means part of the IV is mediated by the MV but other parts are either direct or mediated by other variables not included in the model. In this particular case, the effect of the IV (vocabulary learning attitude) on DV (language skills development) is weakened as shown in the lowered beta value 410 after controlling MV (students' perception towards social media), hence, showing a still significant relationship which implies a partial mediation.

Using the Sobel Z-test, the partial mediation region is not sufficiently large. The result revealed that the mediating effect of students' perception towards social media translates to a more conservative impact in terms of language skills development. It is conservative in the sense that, it fully accounts significant aspects towards language skills development. Evident in the strong association among the variables of the study. However, the partial mediation also translates that of the total effect, almost 60 percent, either direct or mediated by other variables not included in the model.

With the use of Baron and Kenny's (1986) steps in testing mediation of student's perception towards social media, the researcher proved that mediation is significant and there is partial mediation. In addition, the three paths highlighted in the model are supported by the principles of the Classical Multiple Regression Model which revealed the level of linear relationship among the three variables.

The application of the principle of Multiple Regression is appropriate because the data has passed the preliminary analysis by establishing high level of correlation of .439. Apart from the assumption of normality of data, a high level of correlation among the variables is a requirement to do away with spurious model. 


\section{Results:-}

Significance of mediation

Sobel z-value

$95 \%$ Symmetrical Confidence Interval

Lower

Upper

Unstandardized indirect effect

$a * b$

$\mathrm{Se}$

Effect size measures

Standardized Coefficients

Total:

Direct:

Indirect:

Indirect to the total ratio: .217

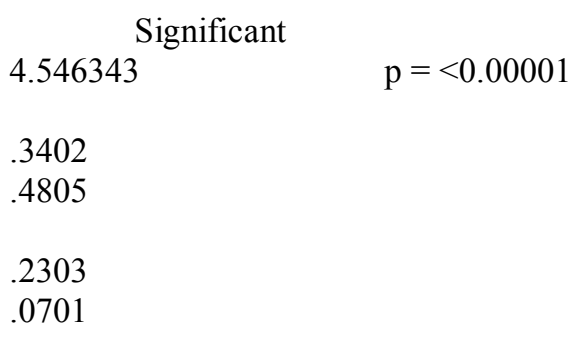

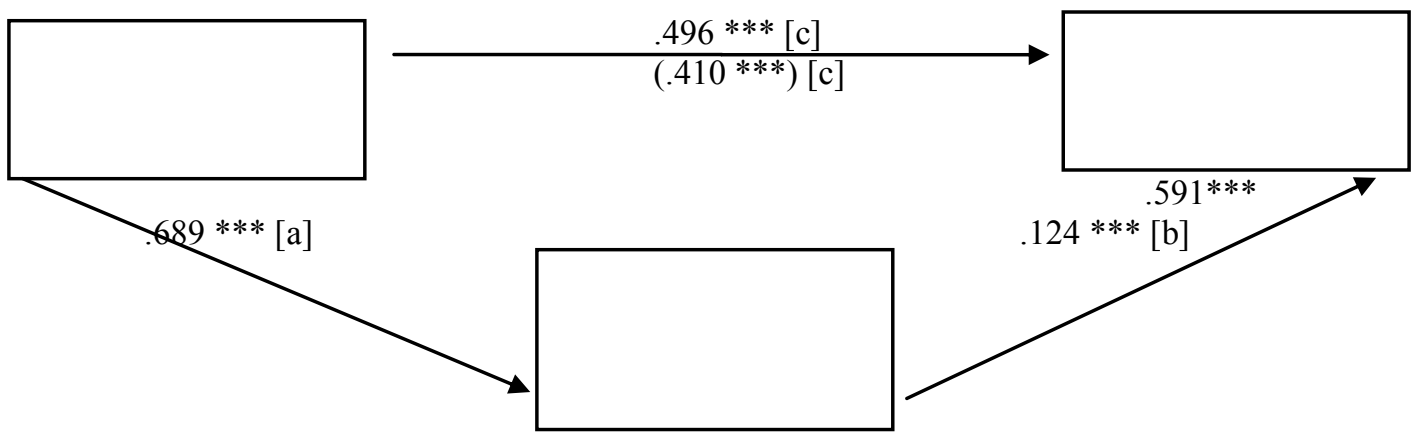

Figure 3:- MedGraph

The Sobel z-value of 4.55 yielded a p-value less than 0.05 , hence significant partial mediation occurred. The association between vocabulary learning attitude (IV) and language skills development (DV) has been significantly reduced by the inclusion of the mediating variable which is students' perception towards social media. It could be seen in the graph that .496 is reduced to .410 in the subsequent regression.

The 95 percent confidence interval conclusively tells that significant mediation has occurred. It yielded a small standard error (se) of 0.04 obtained by subtracting lower limit (.3402) from the upper limit (.4805) and dividing the difference with 3.92 (constant). The small standard estimates measure the precision of the estimate of the coefficient. The rule is that: the smaller the standard error, the more precise the estimate.

The effect size (.397) measures how much of the effect of vocabulary learning attitude (IV) on language skills development (DV) can be attributed to the indirect path (IV to MV to DV). The total effect (.496) is the raw correlation between vocabulary learning attitude (IV) and language skills development (DV). The direct effect (.410) is the size of the correlation between vocabulary learning attitude (IV) and language skills development (DV) with the students' perception towards social media (MV) included in the regression. The indirect effect is the amount of the original correlation between the IV and the DV that now goes through the mediator to the DV (a*b) where "a" refers to the path between IV and MV and "b" refers to the path between MV and DV. The ratio index is computed by dividing the indirect effect to the total effect, in this case .108 divided by $.492=21.7$ percent. It seems that about 21.7 percent of the total effect of the IV on the DV goes through the MV, and about 78.3 percent of the total effect is either direct or mediated by other variables not included in the model.

With the use of Baron and Kenny's (1986) steps in testing mediation of students' perception towards social media, the researcher proved that mediation is significant and there is partial mediation. First regression, the independent variable (vocabulary learning attitude) affects the mediator (students' perception towards social media) at beta coefficient 0.689 and the relationship is significant at p-value equal to 0 . Second regression, the independent 
variable (vocabulary learning attitude) affects the dependent variable (language skills development) at beta coefficient of 0.496 and the relationship is significant at p-value equal to 0 . Third regression, for the mediation to hold, the mediator (students' perception towards social media) affects the dependent variable (language skills development) at beta coefficient value of 0.249 and the relationship is significant at p-value equal to 0 .

Lastly, the dependent variable, (language skills development) is regressed on both independent variable (vocabulary learning attitude) and the mediator (students' perception towards social media). Since the coefficient of the vocabulary learning attitude has been reduced from .496 to 0.410 , but still significant, partial mediation of students' perception towards social media on the relationship between vocabulary learning attitude and language skills development is achieved.

The Sobels $\mathrm{z}$ value of 4.546343 has a probability value of 0.000 significance which is lower than 0.05 level of significance. Hence, a significant mediation is determined and hypothesis 1 is rejected. There is a significant mediation of students' perception towards social media on the relationship between vocabulary learning attitude and language skills development. However, since it is only partial mediation, it could not totally claim that students' perception towards social media were the very reason how vocabulary learning attitude can influence language skills development.

\section{Discussion:-}

The high level of vocabulary learning attitude of students is due to the high rating given by the respondents on the importance of vocabulary and sources of new words. The students are manifesting a good attitude towards learning vocabulary through active class participation and taking down notes during class sessions. These practices, therefore, are expected to increase the learning vocabulary learning attitude since it is in line with the views of various authors (Gifford, 2013; Rashidi \& Omid, 2011; Tam, 2013) who stated the importance of vocabulary and sources of new words contribute to the development of English language skills.

There is a high level of language skills development since the students portrayed a high rating on reading skill, listening skill, speaking skill, and writing skill. Students are showing good language skills development to adapt to the growing demand for learning the English language. Thus, they are doing several learning strategies such as reading on the target language, using media to practice the listening skill, speaking in the target language, and using several references when writing. These language learning strategies help increase language skills development of students. Furthermore, this result is aligned with Tini (1998); and Brown, (2004) affirming that language learners are developing their skills to meet global demands.

The very high level of students' perception towards social media revealed that students view social media positively as a helpful learning tool since they showed a very high rating on interactivity with peers, interactivity with teachers, engagement, perceived usefulness, and students' academic performance. These factors help them develop their language learning since it is parallel with the study of (Gaytan, 2013; Gikas\& Grant, 2013) asserting that rapid development of technologies and existence of social media support learning and motivates students positively.

The test of relationship between vocabulary learning attitude and language skills development revealed a significant relationship between vocabulary learning attitude and language skills development. This implies that the students' vocabulary learning attitude is correlated to language skills development. In other words, the increase in vocabulary learning attitude would also likely increase their language skills development.

This result conforms to the result of Hedgecock and Ferris (2005) proving that vocabulary learning attitude can affect the reading skill of the student meaning, vocabulary learning has a positive contribution to the emergence of successful reading skills. In addition, other studies discovered the positive correlation between vocabulary learning attitude and writing skills (Laufer \& Nation, 1995) similarly, between vocabulary learning attitudes and speaking and listening skill (Joe, Nation, \& Newton, 1996).

Furthermore, the result of this study confirms the contention of Vasu and Senkamalam (2015), claiming that students' vocabulary learning attitude is correlated to all four language skills: listening, reading, writing, and speaking. The results also support the claim of Gifford (2013) that vocabulary is a continuing learning aspect of language, so it is hard to learn a new or second language without learning the vocabulary of that language. 
The test of relationship between students' perception towards social media and language skills development revealed a positive and significant relationship between the indicators of language skills development. This means that the increase in students' perception towards social media would also likely increase language skills development.

This is congruent with the study of Anankulladetch (2017) which confirmed that students' perception towards social media helped improve the language skills of the English language students. This is further reinforced in the findings of Thurairaj et al. (2012), that students' perception towards social media has significant effect to language skills development. Moreover, the progress in information and communication technology (ICT) has made language learning skills development accessible outside the traditional classroom setting (Puthikanon, 2009). Black (2005) also explored how social media affects English language skills, and found out that the group that received learning, engagement, and motivation through a social media site has shown significant development in their language skills.

The test of relationship between students' perception towards social media and vocabulary learning attitude shows that there is a positive and significant relationship between students' perception towards social media and vocabulary learning attitude. This means that the increase in students' perception towards social media would also likely increase vocabulary learning attitude.

This is similar to the result of the study of Khan, Ayaz, and Faheem (2016) which determined that students' perception towards social media can significantly affect the vocabulary learning attitude of the students. Result also strengthens the claim of Linse (2006) that social media platforms have the capability to help English learners enrich their vocabulary through interacting with other social media users. Moreover, according to Huyen and Nga (2003) there are different online games which improve the vocabulary of English language learners in a flexible and relax atmosphere. These online games enhance the interest of English language learners towards the language learning process. Thus the development of English vocabulary is important and plays a dominant role in language learning process as compared to structured learning.

The mediation analysis reveals that, students' perception towards social media partially mediate the relationship between vocabulary learning attitude and language skills development. The partial mediation can hardly claim that students' perception towards social media is the very reason how students' vocabulary learning attitude can influence their language skills development. This indicates that students' perception towards social media can partly explain how vocabulary learning attitude can influence their language skills development. However, the fact that students' perception towards social media has significant correlation with language skills development, this finding is in line with the pronouncement of Wamba and Carter (2016) that students' perception towards social media is an effective tool for language skills development.

Moreover, Harrison and Thomas (2009) explained that the reason why language skills development can be closely associated to social media is because most of the hours spent online is in social networking sites and there are more than 175 million global users. Facebook, for one, is one of the most common social media sites that connects people around the world and offers a platform for interaction and sharing of culture, knowledge, and language.

\section{References:-}

1. Anankulladetch, P. (2017). The impact of social media on ESL students' learning performance. Capstone Projects and Master's Theses, 1(2), 3-6. Retrieved from https://digitalcommons.csumb.edu/cgi/viewcontent.cgi?article=1107\&context=caps_thes_all.pdf

2. Baron, R. M., \& Kenny, D. A. (1986). The moderator-mediator variable distinction in social psychological research: Conceptual, strategic and statistical considerations. Journal of Personality and Social Psychology, 51, 1173-1182.

3. Black, R. W. (2005). Access and affiliation: The literacy and composition practices of English-language learners in an online fan fiction community. Journal of Adolescent \& Adult Literacy, 49(2), 118-128. doi:10.1598/JAAL.49.2.4

4. Brown, H. D. (2004). Language assessment: Principles and classroom practices. New York: Pearson/ Longman, $1(2), 1-3$.

5. Creswell, J. W. (2013). Research design: Qualitative, quantitative, and mixed methods approaches. Newbury, California: Sage Publications. 
6. Gaytan, J. (2013). Integrating social media into the learning environment of the classroom: Following social constructivism principles. Journal of Applied Research for Business Instruction, 11(1), 1-2

7. Gifford, F. (2013). How to enrich your vocabulary? New Delhi, Cyber Tech Publications, 1(2), 256-257.

8. Gikas, J., \& Grant, M. M. (2013). Mobile computing devices in higher education: Student perspectives on learning with cellphones, smartphones \& social media. The Internet and Higher Education, 19, 18-26. doi:10.1016/j.iheduc.2013.06.002

9. GMA News Online. (2018). English proficiency of Pinoy students, teachers lagging survey. Retrieved from https://www.gmanetwork.com/news/news/nation/644114/english-proficiency-of-pinoy-studentsteachers-lagging-survey/story

10. Griffiths, C. (2004). Studying in English: Language skills development. The Modern Language Journal, 73(1), 174-179.

11. Harrison, R., \& Thomas, M. (2009). Identity in online communities: Social networking sites and language learning. International Journal of Emerging Technologies and Society, 7(2), 109-124.

12. Hedgecock, J. S., \& Ferris, D. R. (2005). Teaching ESL composition: Purpose, process, and practice ( $2^{\text {nd }}$ ed.). Mahwah, NJ: Lawrence Erlbaum Associates.

13. Huyen, N. T., \& Nga, K. T. (2003). Learning vocabulary through games. Asian EFL Journal, 5(4), 90-105.

14. Joe, A., Nation, P., \& Newton, J. (1996). Vocabulary learning and speaking activities. English Teaching Forum, 34(1), $2-7$.

15. Junco, R., Heiberger, G., \&Loken, E. (2011). The effect of Twitter on college student engagement and grades. Journal of Computer Assisted Learning,27, 119-132. doi:10.1111/j.1365-2729.2010.00387.x

16. Khan, U., \& Ayaz, M., \& Faheem M. (2016). The role of social media in development of English language vocabulary at university level. Calidoscópio, 13(2), 218-225. doi.org/10.6007/IJARBSS/v6-i12/2444

17. Lau, R. Y. (2012). An empirical study of online social networking for enhancing university students' learning. International Journal of e-Education, e-Business, eManagement and e-Learning, 2, 425 . doi: 10.7763/IJEEEE.2012.V2.158

18. Laufer, B., \& Nation, P. (1995). Vocabulary size and use: Lexical richness in L2 written production. Applied Linguistics, 16(3), 307-322.

19. Linse, C. T. (2006). Practical English language Teaching. International Journal of Learning, Teaching and Educational Research, 8, 119-130.

20. Polkinghorne, F. (2006). Integrating reading and mathematics in business courses. Social Studies, 101(2), 4653. doi:10.1080/00377990903284070

21. Rashidi, N., \& Omid, A. (2011). A survey on Iranian EFL learners' beliefs on the role of rote memorization in learning vocabulary and its effect on vocabulary achievement. Journal of Pan-Pacific Association of Applied Linguistics, 15, 139-161.

22. Sevil, Y. C., \&Yildiz, T. O. (2017). Power comparison of the kolmogorov-smirnov test under ranked set sampling and simple random sampling. Journal of Statistical Computation and Simulation, 87(11), 2175-2185. doi:http://dx.doi.org/10.1080/00949655.2017.1319948

23. Tam, K. (2013). A study on language learning strategies of university students in Hong Kong. Taiwan Journal of Linguistics, 11, 1-42.

24. Thurairaj, S., Roy, S. S., \&Subaramaniam, K. (2012). Facebook and Twitter a platform to engage in a positive learning. International Conference on Application of Information and Communication Technology and Statistics in Economy and Education (ICAICTSEE), 2, 157-166.

25. Tini, T. (1998). English may be ticket to better job in Vietnam. Los Angeles Times. Journal of English and Education, 1, 13-19. Retrieved from http://articles.latimes.com/1998/oct/03/news/mn-28937

26. Tomblin, J.B., Zhang, X., Buckwalter, P., \& Catts, H. (2009). The association of reading disability, behavioral disorders, and language impairment among second-grade children. Journal of Child Psychology and Psychiatry and Allied Disciplines, 41(4) 473-482.

27. Vanderstoep, S. W., \& Johnston, D. D. (2009). Research methods for everyday life blending qualitative and quantitative approaches. San Francisco, USA: Oxford University Press.

28. Vasu, S., \&Senkamalam, P. D. (2015). Understanding the attitude of ESL learners to vocabulary learning. Calidoscópio, 13(2), 218-226. $\quad$ Retrieved from https://search.proquest.com/docview/1776715399?accountid=31259

29. Wamba, S. F., \& Carter, L. (2016). Social media tools adoption and use by English learners. IGI Global,2(2), 791-806.

30. Zimmerman, C. B. (2009). Word knowledge: A vocabulary teacher's handbook. The Electronic Journal for English as a Second Language, 4(13), 1-2.Retrieved from https://eric.ed.gov/?id=ED2097356. 